\title{
COMPETENCE IN LOGISTICS - DESIGNING A META-Model OF Kogistics KNOWLEDGE AREAS
}

NiINE, T.\& KOPPEL, O.

Abstract: Logistics is an extensive interdisciplinary field across industries and jobs, merging the viewpoints of engineering, manufacturing, operations and business administration. In higher education of logistics, various curricula approaches exist from "one-size-fits-all" style to narrow specific focus. However, even when the broad scope is applied in title, the content can vary substantially, often misrepresenting technology topics. This presents a terminological and a practical problem for academia. Competence standards and certifications in logistics differ as well and are not sufficient to drive curricula harmonisation. Our research studies the gaps between models of expected competences from professional logistician. The paper analyses six international standards and presents an augmented structural model of logistics knowledge areas. Such meta-model can be used for effective quantitative curricula evaluation and development and contributes towards refinement of standards.

Key words: logistics competences, logistics knowledge areas, curricula development, competence models, interdisciplinary learning
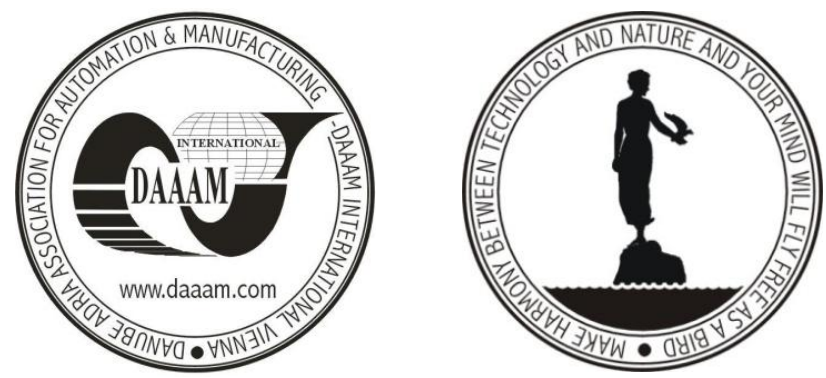

Authors' data: MSc. (Eng.) Niine, T[arvo]; Univ.Prof. Ph.D. Koppel, O[tt], Tallinn University of Technology, Ehitajate 5, 19086, Tallinn, Estonia, tarvo.niine@ttu.ee, ott.koppel@ttu.ee

This Publication has to be referred as: Niine, T[arvo] \& Koppel, O[tt] (2014). Competence in Logistics - Designing a Meta-Model of Logistics Knowledge Areas, Chapter 43 in DAAAM International Scientific Book 2014, pp.543-556, B. Katalinic (Ed.), Published by DAAAM International, ISBN 978-3-901509-98-8, ISSN 17269687, Vienna, Austria

DOI:10.2507/daaam.scibook.2014.43 
Niine, T. \& Koppel, O.: Competence in Logistics - Designing a Meta-Model of Lo...

\section{Introduction}

Logistics is an extensive field reaching across sectors, industries and widely varying responsibilities and job descriptions. Over decades, logistics has evolved into an interdisciplinary concept across the fields of natural and social sciences, merging the viewpoints of engineering and business administration. In both domains, the scope of topics covered by logistics has expanded in time. Recently, integrated treatments of manufacturing, technology design and logistics have seen major developments, further reinforcing the engineering aspect of logistics.

Among such variety and complexity, the core concept of "logistics" remains at the heart of research, monographs, university curricula and competence models. However, the more detailed explanation about the component areas of logistics one would research, the more there are disagreements and mismatches in approaches. This is to some extent taking place already on the definition level, but much more so when detailed models of competences and knowledge areas of logistics professionals are concerned.

In terms of function-specific niches inside logistics, there is relatively less debate. Areas such as warehouse operations or transport planning have their own standards and certification options and universities, if they desire, can build their curricula with more detailed and clear focus. The more interdisciplinary the approach aims to get, the more difficulties for scope it presents. For example, manufacturing logistics support merges production with inventory management, but is also intertwined with purchasing, material handling and ICT topics.

In terms of undergraduate programs, the approach applied by the majority is still generic "logistics" without more specific focus. In all these cases the competence that should be acquired is less clear due to two main factors. One is the wide range of topics that modern logistics entails per se, forcing difficult choices upon curricula designers. Secondly, various international certification and competence model approaches disagree to certain extent among themselves, which means curricula boards are getting mixed messages. In our view, the problem lies in the lack of clarity and harmony across competence standards, which is required for effective curricula development. This paper aims to contribute to reducing the problem by presenting a synthesised meta-model of logistics professional's knowledge areas. The goals of our paper are twofold:

- to identify gaps between standards of logistics competences and fill them;

- to create an integrated tool for "short-cut knowledge-area analysis" of existing curricula as well as developing and positioning new ones.

The structure of this chapter is the following. We start out briefly presenting some relevant points from the literature. Then we focus on the area of competence models in logistics and present a comparison of selected renowned models. The creation and configuration process of our own model is then explained. We also present initial results from pilot-testing our model against a selection of curricula which gave feedback to the model. We conclude with brief discussion of implications and outlining further actions. 


\section{Literature review}

Globalisation and changes in the society keep labour market situation ever evolving (Jirincova \& Leicherova, 2012). Knowledge is a limited resource and importance of knowledge as a driving force of innovation and economic growth worldwide is increasing significantly (Tekic et al, 2013; Sorak \& Dragic, 2013). This prioritises distinguishing between average and excellent employees and the development of performance (Krajcovicova et al, 2012) which in turn effects the competences required from students (Pupavac, 2011). The exact responsibilities of logisticians has been much discussed (Gudehus \& Kotzab, 2009; Schönsleben, 2007). The definition often offered explains logistics via activities that facilitate the coordination of supply and demand in creating time and place utility, which leaves room for various professional interpretations (Simchi-Levy et al 2005, Dinitzen \& Bohlbro, 2010; Erturgut \& Soysekerci, 2011).

Modern logistics is understood as interdisciplinary concept and as such, interfaces with other business functions, as well as to other areas of engineering are abundant. Most textbooks of logistics present some form of a model of the components (David \& Stewart, 2010; Farahani et al, 2011). Perhaps one of the most structured approaches to logistics decision areas has been put forward by Langevin and Riopel (2005) in presenting a structure of 48 decision areas across the levels of strategic planning, physical facility network and operations.

While such approaches offer insight, they are not specific enough to use as direct input for curricula. Furthermore, specific treatments are not internationally agreed upon. Therefore this paper directs attention towards logistics competence standards of wider recognition in hopes that such platforms offer more feasible harmonisation. As far as we know, specific and detailed analysis of various logistician competence models with curriculum development focus has not been carried out before.

\section{Methodology}

\subsection{Input selection criteria}

The criteria for selecting logistician competence models and occupational standards to be included in our study were the following:

1. The model has to focus on "logistics" with a relatively broad view. This means that a model of "distribution and logistics management" would fall into selection as distribution is an integral part of logistics, whereas a model of purely "warehouse management" (such as certification offered by International Warehouse Logistics Association) was not included as logistics is in many dimensions broader than warehousing operations. Another model left out was Certified Logistics Technician (CLT) certification, as it focuses exclusively on technical competencies of front-line material handling and distribution workers.

2. Models focusing purely on "supply chain management" would be excluded stemming from the conceptual understanding that logistics is, though similar, a 
Niine, T. \& Koppel, O.: Competence in Logistics - Designing a Meta-Model of Lo...

distinct concept, at least in terms of academic treatments of professional competences. In our view contrasting logistician and supply chain manager competence models is worthy of separate study and including this dimension here would obfuscate focus. The topic is controversial. There are examples of logistics organisations that certify supply chain managers, such as SCM-PRO certification by Confederation of Indian Industry Institute of Logistics.

3. The model has to describe logistician knowledge areas on professional level suitable for comparison against university or college curricula. Some certification programs strictly require college diploma or degree while others are more flexible, suggesting a combination of work life experience and additional modular training. Some models reference European Qualifications Framework (at least level 5 was required to be included) yet others don't reference the related education level at all. Models clearly focusing on lower positions were left aside.

4. The model must have significant international recognition. Qualification standards of seemingly national reach only were excluded.

5. The model must have clear structure in detailing applicable skills and knowledge areas. For that reason, we did not include Certified Logistics Professional CLP certification by The Logistics and Supply Chain Management Society, among others, as their certification process is built around a scoring calculator of various career-related achievements, but not on specific competences. Their understanding of the reach of logistics is represented by a single sentence, which leaves the system flexible, but extremely subjective. Information on models to study was readily available on the internet.

\subsection{Selected input - relevant competence models}

All considered, it appeared adequate to limit this research with 6 models, which was deemed sufficient to give plentiful ingredients to our meta-model:

- Distribution and logistics managers' competency model by The Association for Operations Management (APICS, 2014);

- Certified in transport and logistics (CTL) by American Society of Transportation and Logistics (AST\&L, 2014);

- Demonstrated master logistician (DML) and Certified master logistician (CML) by The International Society of Logistics (SOLE, 2005);

- International Diploma in Logistics and Transport by Chartered Institute of Logistics and Transport (CILT, 2006);

- Logistics professional by European Logistics Association (ELA, 2014);

- Certified International Trade Logistics Specialist (CITLS) by International Trade Certification (IIEI, 2014).

The Association for Operations Management APICS is one of the more widely known international bodies in logistics. Their model consists of two classes of competencies: foundational and profession-related. While the latter expands into a tree of knowledge areas in "operations management" and "distribution and logistics", the former is mostly structured around personality traits, general skills and attitudes. 
In the view of using APICS model as benchmark for curricula, mostly only profession-related topics would be directly applicable. While it is, of course, relevant to develop traits such as integrity, continuous learning and problem solving ability in any industry-focused training program, the presence of such aspects are largely not identifiable from curricula explicitly. Such aspects are essential for curriculum selfevaluation, but difficult to evaluate from outsider's perspective and this is the reason why our model describes "knowledge areas" not competence, which is a wider concept. Our focus is specific topics which are directly comparable against curricula content and measurable on the level of course titles and descriptions. Keeping that in mind, some items under "academic foundational competencies" in APICS model, such as sections "enterprise economics" and "materials management" were applicable for our research purposes.

American Society of Transportation and Logistics offers multiple levels of certification options: an entry-level oriented "global logistics associate" (GLA), a central and probably most popular "certified in transport and logistics" (CTL) and more exclusive senior-level "distinguished logistics professional" (DLP). CTL presents a flexible framework of three compulsory modules (transport economics, logistics management, international transport and logistics) and three required elective modules of seven (general management principles, lean logistics, logistics analysis, supply chain strategy, logistics finance, supply chain management and creative component). To qualify as CTL, an individual must have earned an undergraduate degree or have at least three years of industry experience. It is worth noting that different to some certification programs, AST\&L also lists universities, the coursework of which is directly counted towards certification.

The International Society of Logistics, with presence in over 50 countries, approaches the topic with more emphasis towards technologies, (being originally The Society of Logistics Engineers) and promotes a balance between logistics management business methods on one side and engineering and industrial processes on the other. SOLE recognition system has five steps: demonstrated logistician, demonstrated senior logistician, demonstrated master logistician, certified master logistician (CML) and certified professional logistician (CPL). Each step on the career path imposes logistics job performance and continuing education requirements as well as additional lists of related functional skills and enabler skills training areas. Workplace experience and education degree and coursework requirements are interrelated and flexible - a defined amount of courses needs to be passed for every recognition level from a large list of electives. According to SOLE, applicants with master's degree are invited to CML levels directly. SOLE suggest a model of typical educational areas appropriate to logistics designation programs, which is built around four pillars: systems management, systems development and design, acquisition and product support and distribution and customer support.

The UK-based Chartered Institute of Logistics and Transport (CILT), with members in 30 countries, offers three levels of certification: International Certificate in Logistics and Transport (level 3 in EQF), International Diploma in Logistics and Transport (level 5 in EQF) and International Advanced Diploma in Logistics and Transport (level 6 in EQF i.e. "degree level"). According to the diploma guide: "The Diploma is aimed at those already working in the industry/sector at a middle management level and who wish to develop a strategic view of logistics and transport 
operations". The course content is divided into six modules: logistics operations, resources, transport economics and finance, logistics and supply chain, inventory and warehouse, and finally passenger transport. Advanced diploma adds a layer of five knowledge areas relating to strategic performance management. The range of topics is extensive on both levels, but are intended to be completed in only 360 hours.

A similar structure of three levels is suggested by European Logistics Association: supervisory and operational management of logistics (EQF level 4), senior management of logistics (level 6), and strategic management of logistics (level 7). ELA is a federation of 30 national organizations, situated in Central and Western Europe. The mission of ELA is to offer certification that follows industry trends and is suitable for international evaluation, training and recruitment. Both level 4 and level 6 ELA standards consist of four key skill areas: business principles, logistics design, supply chain and logistics planning and execution, with latter further expanding into transport, warehousing, customer service and sourcing topics.

IIEI International Trade Certification has defined altogether 10 standards for various positions concerning international trade operations. While some of them are clearly too narrow to be used in this research, such as Certified International Freight Forwarder, the Certified International Trade Logistics Specialists (CITLS) suggests a broad range of knowledge areas, which IIEI calls "an in-depth synopsis of Supply Chain Management concentrating on the exporting/importing environment". The CITLS model is essentially a long list of over 30 topics as specific knowledge areas expected from logistics specialist operating in international trade.

\subsection{Logistics knowledge areas - model configuration}

Our process of research steps undertaken along with results from each steps are presented on Fig. 1 below.

\begin{tabular}{|c|c|}
\hline $\begin{array}{l}\text { STEP 1: selection of suitable competence } \\
\text { models }\end{array}$ & - result: 6 competence models selected \\
\hline STEP 2: comparative analysis of selection & $\begin{array}{l}\text { - result: visualised relations of models } \\
\text { - gaps and mismatches identified }\end{array}$ \\
\hline $\begin{array}{l}\text { STEP 3: disintegrating models into fragments } \\
\text { and pooling }\end{array}$ & $\begin{array}{l}\text { - result: "melting pot" of over a thousand } \\
\text { items of topics and skills }\end{array}$ \\
\hline $\begin{array}{l}\text { STEP 4: sorting the mix and outlining } \\
\text { emerging strutcure }\end{array}$ & - result: classification of knowledge areas \\
\hline $\begin{array}{l}\text { STEP 5: refining the level of detail of } \\
\text { elements in the new structure }\end{array}$ & $\begin{array}{l}\text { - result: detailed lists of elements of } \\
\text { knowledge and expertise }\end{array}$ \\
\hline $\begin{array}{l}\text { STEP 6: pilot-testing model with a sample of } \\
\text { logistics curricula }\end{array}$ & $\begin{array}{c}- \text { result: curricula-oriented analytical tool } \\
\text { of logistician knowledge areas }\end{array}$ \\
\hline
\end{tabular}

Fig. 1. Implemented research process and outcomes

Even without delving deep into our selection, it was clear that models were far from describing the same scope. Being perfectly competent to be certified by any one of these models would not automatically assume certification success according to others. The models differ in scope, in structure, in the level of detail described and in the approach used to describe the details, whether from the viewpoint of knowledge areas (i.e. understands, is knowledgeable about....) or skills (i.e. skilled in performing, 
evaluates, identifies, manages, demonstrates etc.). The extent of differences referred in step 2 are in more detail demonstrated in the following section.

To merge the knowledge areas of all the models, it would be possible to use any one structure as a basis and "fill in the gaps". However, we felt that none of the structures were perfect in terms of classifying knowledge areas directly from teaching viewpoint rather than performance-in-workplace view that most standards are based on. Hence heavy restructuring of topic divisions appeared unavoidable. Careful to avoid bias, we split models into component fragments, merged the fragment pools and sorted the elements into reasonable structure for curricula analysis. The initial pool was a notable mess which further demonstrated substantially different ways to present the mind of a logistician.

While step 3 was purely mechanical, steps 4 and 5 required thoughtful considerations, keeping in mind both the integrity as well as practical usability of the emerging model. To demonstrate the application of our model, pilot-testing was done and the findings from step 6 were used as feedback to further refine it.

The principle of the model is simple. It consists of 20 knowledge areas, with each section containing 9-12 elements that should belong to logistician's training. The model is sizeable and presented in the appendix. For example, section "manufacturing process and technologies" includes 11 elements, items such as "manufacturing capacity planning", "CAD-CAM systems" and "quality assurance". While they do not belong to the heart of logistics, the interfaces are still relevant. For each item, the evaluation can have three outcomes: 1) it is explicitly embedded in the curriculum; 2) inclusion of the topic in the curriculum appears indirect, with more distant wording, as a possible component under a more general heading or if a wider topic field forms only a small part in one course (this mitigates the case when publicly available data is less than perfect); 3 ) there is no indication that the topic is included in the curriculum. Mathematically it is just $1.0,0.5$ or 0 and the average rating across each of the 20 sections is finally what is measured. This means, for each curriculum analysed, we can identify to what extent is the program able to fill each section. In percentage values, each curriculum is represented by a vector $\mathrm{CUR}_{\mathrm{i}}$.

$$
\operatorname{CUR}_{\mathrm{i}}=\left(\mathrm{a}_{1}, \mathrm{a}_{2} \ldots \mathrm{a}_{20}\right)
$$

In (1), $a_{x}$ is identified coverage of analysed curriculum on given section. Done across sections, this would give insight into the actual profile of the curriculum regardless of titles and marketing. With adequate specific data of a large pool of curricula, this would allow to run a 20-dimensional cluster analysis for better understanding how general logistics curricula are actually built up and what are the most common types of approaches.

We note that our analytical tool is more suitable for comparing the scope and focal issues of content of any curricula against another rather than giving the said curriculum a "quality level" as the quality of education is on many levels a higher concept than just declarative curriculum content. Still an approximate quantitative indication of a level of coverage of a curriculum against our benchmark model offers meaningful interpretations. Therefore the model can be used as a basis for simple 
Niine, T. \& Koppel, O.: Competence in Logistics - Designing a Meta-Model of Lo...

gap-analysis. Whilst actually identifying quality level of all the courses requires specific customer satisfaction input, at least the scope of the program can be measured quickly, which is why we call it "the short-cut knowledge-area analysis".

In the following section, we first turn attention towards findings from step 2, then describe the process in steps 4 and 5 and conclude with findings from step 6 .

\section{Data}

\subsection{The gaps between component models}

In terms of scope and structure, the differences between models can best be visualised on a diagram. For the sake of brevity, we'll present graphically only the comparison of two models here: between APICS and ELA in Fig. 2. Fig. 2 represents the simplified model of ELA in the middle, composed of nine sections, and the model of APICS laid around it in two core pillars: "logistics and distribution" and "operations management" knowledge areas. The idea of such comparison is to focus on all subcomponents of APICS (16 and 8 on sides) and evaluate their relation to ELA model. Continuous lines represent close to full coverage of that APICS element by ELA, cut lines demonstrate partial coverage and links to the question mark point that either a small proportion (dashed line) or a significant amount (continuous line) of elements are not specifically included by ELA.

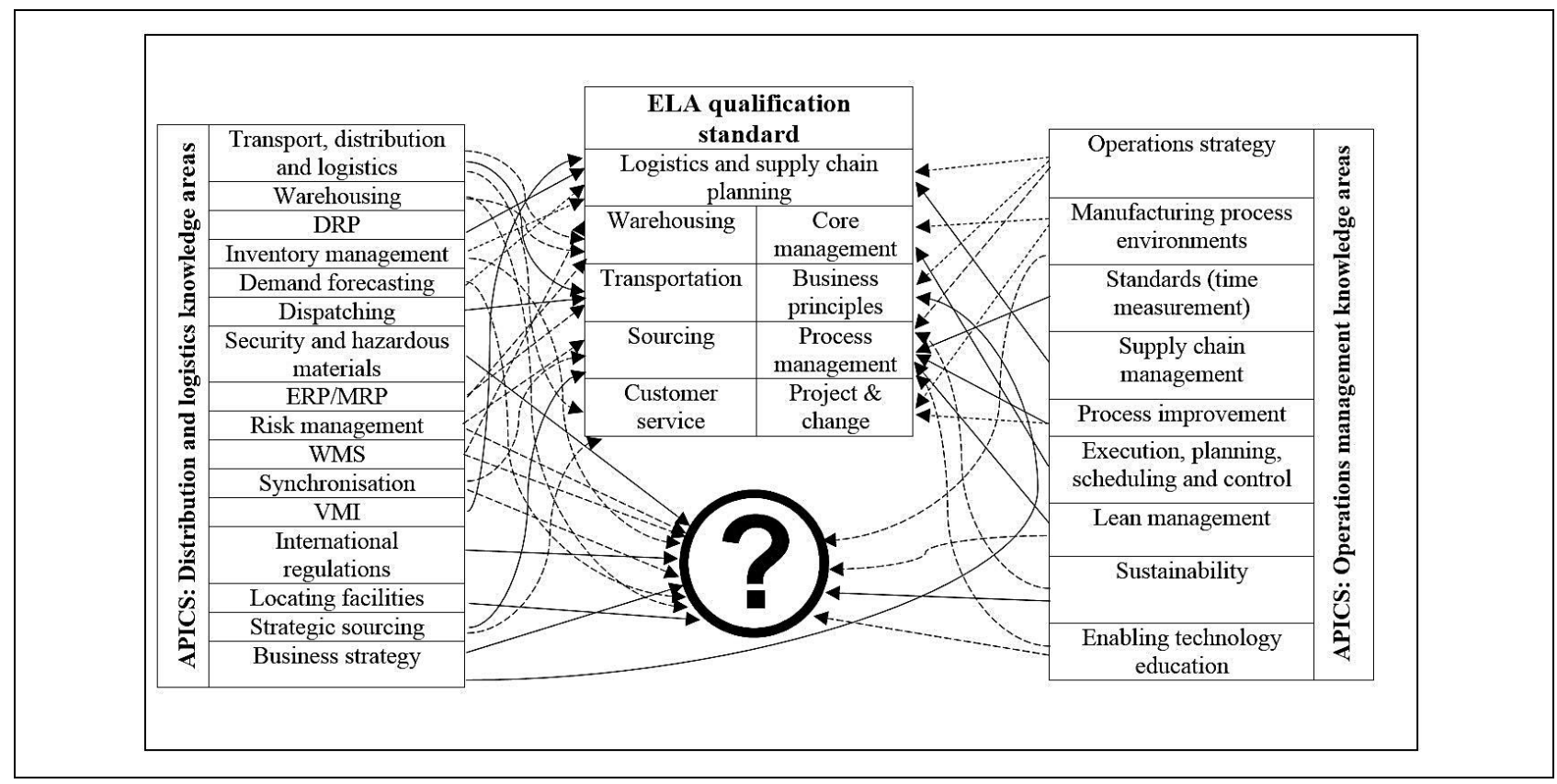

Fig. 2. Relations between ELA and APICS models of logistics competences

We would like to point out both the abundance of connectors on the figure, representing differences in structure, as well as a notable proportion left uncovered. While figure 2 could be mistaken as a direct criticism of ELA competence model, it is not our intent as all the models we've reviewed have their gaps. Other models, for instance CITLS, can point out further gaps in both ELA and APICS and yet in contrast, both of them are about ten times bigger and much richer in details compared to CITLS. We have noted that both ELA and APICS have also some overlap between 
the categories of the very same model. In short, modelling the content in logistics is not an easy task. One lesson to be learned, on both the levels of competence models as well as curricula, is that the more there are category divisions, the more there are interfaces between them and these relationships need to be carefully managed to guarantee essentials are covered with as little overlap as possible.

\subsection{Emerging classification of knowledge areas}

In terms of process-oriented versus knowledge-oriented learning outcomes, we knowingly leaned towards latter, as that suited the main goal, to develop a tool for curricula analysis, better. Essentially, some task-based viewpoints were altered to be knowledge-based. This often meant merges and simplifications - a process-oriented model might suggest "assists manufacturing management in the development of meaningful productivity and performance measurements" and "ensures the alignment of the materials management strategy with the business strategy". In our approach, it became "manufacturing performance analysis", because this is the level of detail met in curriculum and it would make sense various aspects of it together. Such transfer from detailed operational aspects to broader knowledge areas meant that our model would consist of roughly few hundred elements, while the former would have been many times larger even after removing the duplicates.

Before the final level of detail was in focus, the question of structure had to be decided. In this regard, a problem similar to organising logistics in practice was met reaching strictly functional division of aspects is almost impossible due to interlinking viewpoints. It initially appeared rational to postulate three levels of knowledge areas: a level of general business administration topics, one for issues that we felt formed the core of business logistics management in a broad sense (in terms of service, network and flow management) and one for all kinds of issues in managing typical functions in logistics (transport, warehousing, ICT etc.).

As the third level was still the most abundant in information (after all, logistician must know the details, not only "the big picture"), it was decided to separate transport-related topics. Such division allowed for placing the elements of manufacturing and systems engineering next to warehousing and ICT technologies and the entire section was labelled "supporting technologies, processes and systems engineering". We note that while inventory management is conventionally treated as a functional area, we'd argue that from the practical business point of view inventory issues form a core of logistics even more than transport so we treated inventory management with a spot in the section of core issues. For all practical purposes of this model, the relative position of subsections matters less than actual scope and content.

Finally some viewpoints remained on the table that reached across other levels, specifically various legal, sustainability and risk management issues. On one hand, separating these aspects means introducing overlap into sections (such as transport law belonging both other transport and legal issues). However, another consideration is that including these aspects separately would give the model better functionality in evaluating the strengths and weaknesses of any given curriculum from more viewpoints and would allow to observe more dimensions. We decided to favour the 
Niine, T. \& Koppel, O.: Competence in Logistics - Designing a Meta-Model of Lo...

latter approach. For practical purposes the loss in measurement accuracy because of few similar topics existing twice in the model, is minimal.

This left us with 19 subsections with fragments still needing substantial consolidation. In addition, there were some topics left which formed foundational knowledge in various fields of sciences, both natural and social: statistics, physics, ethics etc. These aspects are seldom included in competence models but they can sometimes account for notable curriculum space. Therefore, as seen on Fig. 3, we added final section titled "basics of natural and social sciences".

\begin{tabular}{|c|c|c|c|}
\hline \multicolumn{4}{|c|}{ Level A: General business administration } \\
\hline $\begin{array}{l}\# 1 \text { : Business strategy } \\
\text { and marketing }\end{array}$ & $\begin{array}{l}\text { \#2: Financial } \\
\text { management and costs }\end{array}$ & $\begin{array}{l}\text { \#3: Organization, } \\
\text { people and workflow }\end{array}$ & $\begin{array}{c}\text { \#4: Operations } \\
\text { management and } \\
\text { process improvement }\end{array}$ \\
\hline \multicolumn{4}{|c|}{ Level B: Broad logistics core } \\
\hline $\begin{array}{l}\# 5 \text { : Supply chain } \\
\text { management core } \\
\text { concepts }\end{array}$ & $\begin{array}{c}\text { \#6: Logistics } \\
\text { operations, network and } \\
\text { system }\end{array}$ & $\begin{array}{l}\text { \#7: Purchasing and } \\
\text { supply management }\end{array}$ & $\begin{array}{r}\# 8 \text { : Inventory } \\
\text { management }\end{array}$ \\
\hline \multicolumn{4}{|c|}{ Level C: Viewpoints on transport } \\
\hline $\begin{array}{l}\# 9 \text { : Operational } \\
\text { transport }\end{array}$ & $\begin{array}{l}\# 10 \text { : Transport: society } \\
\text { and systems view }\end{array}$ & $\begin{array}{l}\text { \#11: Field-specific } \\
\text { transport economics }\end{array}$ & $\begin{array}{l}\text { \#12: Transport } \\
\text { technology }\end{array}$ \\
\hline \multicolumn{4}{|c|}{ Level D: Other technology, process and systems engineering viewpoints } \\
\hline $\begin{array}{l}\text { \#13: Systems } \\
\text { engineering and } \\
\text { development }\end{array}$ & $\begin{array}{l}\text { \#14: Warehousing } \\
\text { process and } \\
\text { technologies }\end{array}$ & $\begin{array}{l}\text { \#15: Information and } \\
\text { communication } \\
\text { technologies }\end{array}$ & $\begin{array}{l}\text { \#16: Manufacturing } \\
\text { process and } \\
\text { technologies }\end{array}$ \\
\hline \multicolumn{4}{|c|}{ Level E: Cross-functional supporting viewpoints } \\
\hline $\begin{array}{l}\text { \#17: Legal environment } \\
\text { in logistics }\end{array}$ & $\begin{array}{l}\text { \#18: Sustainability in } \\
\text { logistics }\end{array}$ & \#19: Risk analysis & $\begin{array}{l}\# 20 \text { : Basics of natural } \\
\text { and social sciences }\end{array}$ \\
\hline
\end{tabular}

Fig. 3. Consolidated and refined model of knowledge areas of logistics professionals

Structurally, this section appeared to fit along other interdisciplinary aspects, so the final section of the model was renamed to "cross-functional supporting viewpoints". This also simplified the structural framework of the model, which appears to reflect the extent to which modern understanding of logistics has grown. The components of each section are listed in appendix.

\subsection{Pilot-testing with curricula}

The model was tested by comparing it against five undergraduate logistics curricula. We list them here but present the data as anonymous lines on figure 4 not to be blamed for malevolent intent in case either the input data was outdated, lacking or the measurement came out slightly incorrect. The curricula evaluated were:

- "International logistics management" - Upper Austria University of Applied Sciences, Steyr, Austria;

- "Business logistics and transport management" - University of Greenwich, UK;

- "Logistics" - Tallinn University of Technology, Estonia;

- "Business logistics" - Riga Technical University, Latvia;

- "Logistics engineering" - JAMK University of Applied Sciences, Finland. 
We note that some curricula cannot be studied objectively because of a lack of publicly available data. While most universities list the courses (yet some list only modules and are protective of details), the description of course content can range from a few lines to about a full page. The model will not work accurately if there is more taught in classroom than shown on paper. These are considerations when attempting to gather data on large pool of curricula. However, when the curriculum input is detailed, the analysis takes only around 45-60 minutes.

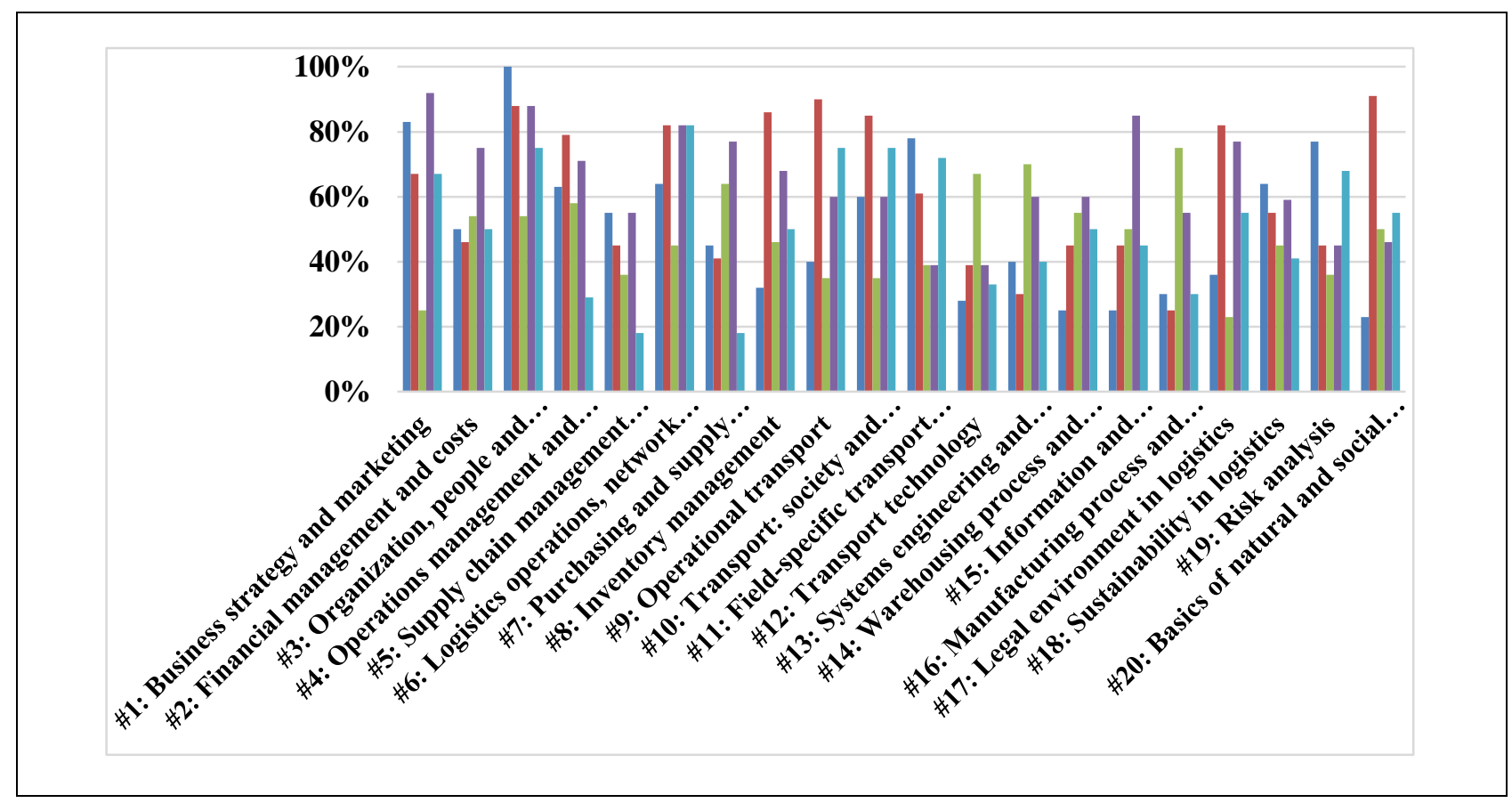

Fig. 4. Five logistics curricula benchmarked against our knowledge-area model

In evaluating the curricula, minor additions to model components and tweaks to formulation were made. In some cases, the components inside each section do not cover the section completely, which would be practically impossible, but still present enough variety so that the evaluation results in a meaningful rate of relative coverage.

Our limited testing confirmed our expectations - we have not yet observed a close-to-complete treatment of topic areas in any curriculum. The contrasts and gaps in our small sample were larger than anticipated. The argument of intended curricula differentiation might be a partial explanation, but it is still strange, for example, when a curriculum is stronger on engineering side in general and yet falls unexpectedly short in some technology area that would logically belong to such profile.

One can easily argue that completeness is essentially unachievable due to program capacity constraints. Fig. 4 reveals average coverage rates only around 50$60 \%$. Still some manage notably better than others and all five curricula have their weaknesses where coverage rate falls below $40 \%$. We suspect the issue lies at least partially in lack of benchmarking in logistics education. What the data on figure 4 indicates is that there is room for improvement in any logistics curriculum. 


\begin{tabular}{|c|c|c|c|}
\hline \multicolumn{4}{|c|}{ Level A: General business administration topics } \\
\hline $\begin{array}{l}\text { \#1: Business strategy } \\
\text { and marketing }\end{array}$ & $\begin{array}{c}\text { \#2: Financial } \\
\text { management and costs }\end{array}$ & $\begin{array}{c}\text { \#3: Organization and } \\
\text { people }\end{array}$ & $\begin{array}{l}\text { \#4: Operations } \\
\text { management }\end{array}$ \\
\hline Market research & Financial statements & Decision-making tools & Demand forecasting methods \\
\hline Business environment analysis & Investment analysis & Organisation behaviour & Available capacity analysis \\
\hline Market positioning & Financial ratio analysis & Motivation theories & Supply and demand synchronisation \\
\hline Strategic management & Activity based costing & Incentive and reward systems & Operations performance analysis \\
\hline Competitive environment & Total supply chain cost analysis & Training and development & Innovation and creativity \\
\hline Portfolio planning & Customer-based profitability & Leadership and delegation & Waste analysis and reduction \\
\hline International marketing & Strategic pricing & Project management & LEAN process improvement \\
\hline New product development & Asset utilization analysis & Teamwork & Six sigma \\
\hline Product promotion & Budget planning and control & Effective communication & Root cause analysis \\
\hline Logistics strategy & Lifecycle costs & Organisation structure & TOC Theory of Constraints \\
\hline Industry benchmarking & Cash flow management & Process analysis and job design & TQM Total Quality Management \\
\hline Product lifecycle management & Funding & Change management & JIT and pull system management \\
\hline \multicolumn{4}{|c|}{ Level B: Logistics "big picture" core topics } \\
\hline $\begin{array}{l}\text { \#5: Supply chain } \\
\text { management core }\end{array}$ & $\begin{array}{l}\text { \#6: Logistics network } \\
\text { and system }\end{array}$ & $\begin{array}{c}\text { \#7: Purchasing and } \\
\text { supplies }\end{array}$ & $\begin{array}{l}\text { \#8: Inventory } \\
\text { management }\end{array}$ \\
\hline Supply chain competitive advantage & Logistics performance objectives & Sourcing strategies & Inventory performance analysis \\
\hline Value chain management & Key performance indicators & Supplier selection criteria analysis & Inventory costs \\
\hline Value creation analysis & Customer service standards & Contract negotiations & Inventory classification \\
\hline Supply chain mapping & Lead time and order cycle time & Supplier performance evaluation & Inventory deficit impact analysis \\
\hline Supply chain configurations & Logistics cost categories & Purchasing costs & Methods of inventory valuation \\
\hline SCOR model & Cost trade-off management & Types of purchasing arrangem & Economic order quantity \\
\hline Agile supply chain & Facility location analysis & Supply chain collaboration & Safety stock calculations \\
\hline Postponement & DRP & Supplier base rationalisation & Ordering systems \\
\hline Mass customization & Transaction documents & Supplier relationship management & Bullwhip effect \\
\hline $\mathrm{QR} / \mathrm{ECR}$ & 3PL and 4PL concepts & Cross-cultural communication & ABC-categorization \\
\hline S\&OP Sales and Operations Planning & Make-or-buy analysis & CPFR-model & Vendor managed inventory \\
\hline \multicolumn{4}{|c|}{ Level C: Viewpoints on transport } \\
\hline $\begin{array}{l}\text { \#9: Operational } \\
\text { transport }\end{array}$ & $\begin{array}{l}\text { \#10: Transport: society } \\
\text { and system }\end{array}$ & $\begin{array}{l}\text { \#11: Field-specific } \\
\text { transport }\end{array}$ & $\begin{array}{l}\text { \#12: Transport } \\
\text { technology }\end{array}$ \\
\hline Transport performance objectives & Global cargo flows & Freight forwarding & Road transport technologies \\
\hline Carrier types and service conditions & Transport infrastructure & Road transport & Rail transport technologies \\
\hline Carrier selection and contracting & History of transport & Rail transport & Maritime transport technologies \\
\hline Transport mode selection & Supply and demand in transport & Airfreight transport & Aviation technologies \\
\hline Load and route planning & Transport policy design and goals & Sea and waterway transport & Pipeline transport technologies \\
\hline Transport of hazardous materials & Socio-economic investment analysis & Public transport & Passenger transport technologies \\
\hline Transport of oversized cargo & Full costs of transport & Airlines and air travel & Support infrastructure technologies \\
\hline Vehicle and cargo tracking & Transport external costs & Intermodal terminal management & Intermodal terminal technologies \\
\hline Load fastening and protection & Transport market regulation & Port management & Intelligent transport systems \\
\hline Road tolls, local regulations & Taxes and charges in transport & & \\
\hline \multicolumn{4}{|c|}{ Level D: Other technology, process and systems engineering viewpoints } \\
\hline $\begin{array}{l}\text { \#13: Systems } \\
\text { engineering }\end{array}$ & \#14: Warehousing & $\begin{array}{c}\text { \#15: IT and } \\
\text { information systems }\end{array}$ & \#16: Manufacturing \\
\hline Supply chain process modelling & Warehouse performance objectives & Data warehousing & Manufacturing performance analysis \\
\hline Logistics systems engineering & Warehouse capacity planning & E-commerce & Manufacturing capacity planning \\
\hline Information system engineering & Storage condition requirements & ERP systems & Manufacturing process analysis \\
\hline Product development & Handling of hazardous materials & Information system modelling & Master production schedule \\
\hline Infrastructure engineering & Cross-docking operations & EDI electronic data interchange & MRP Material requirement planning \\
\hline Traffic engineering & Conventional warehouse equipment & Data security and privacy & Kanban system \\
\hline Facility layout engineering & Automated storage and retrieval & Automated identification standards & Manufacturing technologies \\
\hline Reliability engineering & Packaging materials and technologies & RFID-technology applications & Advanced materials \\
\hline Maintainability engineering & Unitization optimization & Warehouse management systems & CAD-CAM systems \\
\hline Safety engineering & Inventory control techniques & Management information systems & Quality assurance and control \\
\hline \multicolumn{4}{|c|}{ Level E: Cross-functional supporting viewpoints } \\
\hline $\begin{array}{c}\text { \#17: Legal } \\
\text { environment }\end{array}$ & $\begin{array}{l}\text { \#18: Sustainability in } \\
\text { logistics }\end{array}$ & \#19: Risk analysis & $\begin{array}{c}\text { \#20: Natural and social } \\
\text { sciences }\end{array}$ \\
\hline Basics of law & Climate change impact and risks & Risk management process & Calculus \\
\hline Commercial law & Alternative fuels & Physical cargo risks & Statistics \\
\hline Competition law & Modern vehicle technologies & Ergonomics and human safety & Physics \\
\hline Labor law & Air quality and emission standards & Environmental risks & Chemistry \\
\hline Intellectual property law & Congestion charging & Economic risks & Logic \\
\hline Customs regulations & Travel demand management & Financial transaction risks & Environmental science \\
\hline Taxes and taxation & Carbon footprint of business & Technological disruptions & Philosophy \\
\hline International trade agreements & Triple bottom line concept & Regulatory and compliance risks & Ethics \\
\hline Documents and licenses in logistics & Renewable resources and energy & Supply chain security & Micro-economics \\
\hline International transport conventions & Regulations on waste and recycling & Risk mitigation strategies & Human geography \\
\hline Incoterms regulations & Reverse logistics & Contingency planning & Sociology \\
\hline
\end{tabular}

Tab. 1. A meta-model of logistics knowledge areas 


\section{Conclusion}

The paper studied the problem of discrepancies in competence models and undergraduate curricula in the field of logistics. We approached the issue by synthesising a meta-model of knowledge areas of logistics professionals, with an intent of utilising it as a tool for existing curricula benchmarking analysis.

The first conclusion based on limited testing of our model is that the differences between logistics curricula can be substantial. Partially this can be seen as the result of universities knowingly attempting to differentiate, due to physical constraints and lack of strong unified vision of the reach of logistics, yet partially because logistics as a field has grown too big to cover. One could exaggerate and say "there is no logistics", just selections of topics in various combinations. Of course the heart of logistics, namely transport planning, inventory, material handling and IT technologies, is mostly present everywhere, but with much varying flavours.

For broader conclusions our future plan is to analyse more curricula. While data availability is still a relevant constraint, it is our observation that a trend exists to publish more detailed course information in university websites. Our quantitative approach could be used to carry out statistical cluster analysis of curricula to group similar programs and identify the variety of approaches in teaching logistics. This would allow curricula to be better positioned and refined.

For us, the findings are not just a theoretical curiosity but the model can be applied in curriculum development. Firstly it would help curricula boards to understand "how big is the big picture". Secondly, should the board knowingly decide to offer more differentiated niche program, the model offers the dimensions to consider and also allows to chart closest competing programs so that differentiation would be more effective. Of course, in all these cases, it should be really important to stress that such programs would need to be called something more specific than just "logistics" (or "supply chain management"). Our conclusion is - if full coverage of logistics is attempted by curriculum, it demands careful attention to avoid gaps and also overlap which is also easy to happen without integrated course development. We hope our model contributes to more efficient development of new curricula.

\section{References}

APICS The Association for Operations Management (2014) "Distribution and Logistics Managers Competency Model” APICS, p. 23

AST\&L American Society of Transportation and Logistics (2014) "Certification in Transportation and Logistics Information Booklet", AST\&L, p. 12

CILT Chartered Institute of Logistics and Transport (2006) "International Diploma in Logistics and Transport. Standards of Knowledge and Competence" CILT, p. 28 David, P.A.; Stewart, R.D. (2010) "International Logistics: The Management of International Trade Operations" Cengage learning, ISBN 978-1-1114-6498-1 p.439 
Niine, T. \& Koppel, O.: Competence in Logistics - Designing a Meta-Model of Lo...

Dinitzen, H.B.; Bohlbro, D. (2010) "Value-Added Logistics in Supply Chain Management" Academica, Denmark, ISBN 978-87-7675-847-9, p. 254

ELA European Logistics Association (2014) "European Qualification Standards for Logistics Professionals"

Erturgut, R.; Soysekerci, S. (2011) "Professional manager education on logistics and supply chain management" Procedia Social and Behavioral Sciences 15, 2011, 2771-2775, ISSN 1877-0428

Farahani, R.; Rezapour, A.; Kardar, L. (2011) "Logistics Operations and Management Concepts and Models" Elsevier, ISBN 978-0-12-385202-1, p. 475

Gudehus, T.; Kotzab, H. (2012) "Comprehensive Logistics" $2^{\text {nd }}$ ed. Springer-Verlag Berlin, ISBN 978-3-642-24366-0, p. 935

IIEI International Trade Certification (2014) "Certified International Trade Logistics Specialist CITLS" [WWW] http://www.iiei.org/ Accessed on 2014-08-12

Jirincova, M.; Leicherova, V. (2012) "The awareness of diversity among the Czech students and graduates" Annals of DAAAM for 2012 \& Proceedings of the 23rd International DAAAM Symposium, Volume 23, No.1, ISSN 2304-1382, published by DAAAM International, Vienna, Austria, EU, 2012

Krajcovicova, K.; Caganova, D.; Cambal, M. (2012) "Key managerial competencies and competency models in industrial enterprises", Proceedings of the 23rd International DAAAM Symposium, Volume 23, No.1, ISSN 2304-1382, ISBN 9783-901509-91-9, Ed. B. Katalinic, Published by DAAAM International, Vienna, Austria

Langevin, A.; Riopel, D. (2005) "Logistics Systems Design and Implementation" Springer, ISBN 0-387-24971-0, p. 401

Pupavac, D. (2011) "The analysis of entrepreneurial activity of students of professional studies", Proceedings of the 22nd International DAAAM Symposium, Volume 22, No. 1, ISSN 1726-9679, published by DAAAM International, Vienna, Austria

Schönsleben, P. (2007) "Integral Logistics Management" $3^{\text {rd }}$ ed. Auerbach Publications, Taylor \& Francis Group, ISBN 978-1-4200-5194-0, p. 1064

Simchi-Levi, D.; Chen, X.; Bramel, J. (2005) "The Logic of Logistics. Theory, Algorithms, and Applications for Logistics and Supply Chain Management" $2^{\text {nd }}$ ed. Springer, ISBN 0-387-22199-9, p. 365

SOLE The International Society of Logistics (2005) "The Designated Logistician Program", SOLE, p. 9

Sorak M.; Dragic M. (2013) "Supply Chain Management of Small and MediumSized Enterprises", Chapter 59 in DAAAM International Scientific Book 2013, pp. 951-968, B. Katalinic \& Z. Tekic (Eds.), Published by DAAAM International, ISBN 978 -3-901509-94-0, ISSN 1726-9687, Vienna, Austria

Tekic, Z; Kukolj, D; Drazic, M; Vitas, M (2013) "Towards understanding the role and value of patents in a knowledge-based economy", Chapter 25 in DAAAM International Scientific Book 2013, pp. 459-474, B. Katalinic \& Z. Tekic (Eds.), Published by DAAAM International, ISBN 978-3-901509-94-0, Vienna, Austria 